\title{
Surgical Procedures Performed in Management of Malignant Pleural Effusions
}

\author{
Tunç Laçin ${ }^{1}$, Salih Topçu²
}

${ }^{1}$ Clinic of Chest Surgery, Süreyyapaşa Chest Diseases and Thoracic Surgery Training and Research Hospital, İstanbul

${ }^{2}$ Department of Chest Surgery, Kocaeli University Faculty of Medicine, Kocaeli

\begin{abstract}
Malignant pleural effusion is one of the most common clinical problems in neoplastic diseases. There is no optimum treatment available. Pleurodesis is the most frequent method used for the treatment of malignant pleural effusion. However, in cases where pleurodesis failed more invasive procedures such as permanent catheter application, pleurectomy, decortication and extrapleural pneumonectomy can be used. In this paper, surgical treatment of malignant pleural effusion, were evaluated by reviewing the most recent articles.
\end{abstract}

Keywords: Indwelling catheters, malignant pleural effusion, pleurectomy, pleurodesis, talc, videothoracoscopy

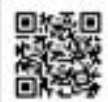

Received Date: 28.05.2013 Accepted Date: 31.07 .2013

Address for correspondence

Salih Topçu, Department of Chest Surgery, Kocael University Faculty of Medicine, Kocaeli, Turkey

E-mail: drsaliht@yahoo.com \section{(1) 3 This work is licensed under a Creative} 4.0 International License.

DOI: $10.5152 /$ ejp.2014.50133

- Available online at www.eurasianjpulmonol.com

\section{INTRODUCTION}

Malignant pleural effusions constitute $22 \%$ of all pleural effusions, and more than 150,000 new cases are diagnosed each year in the United States (1). Malignant pleural effusion occurs with the primary cancer of any organ metastasis to pleura and indicates a poor prognosis. In approximately half of the cancer patients, metastatic malignant pleural effusion develops throughout the course of the disease (2). Depending on the type of neoplasm, the approximate survival time after the diagnosis of malignant pleural effusion is 4-6 months (3). The main problems observed among patients with effusion are dyspnea, chest pain (primarily depending on the parietal pleura and chest wall involvement), and decrease in the quality of life depending on the developing symptoms such as cough.

It is known that symptomatic malignant pleural effusion develops through the course of the disease in $50 \%$ of patients with breast cancer, $25 \%$ of patients with lung cancer, and more than $90 \%$ of patients with mesothelioma $(3,4)$. The treatment of malignant pleural effusions is determined according to the patient's symptoms and performance status, primary tumor and tumor response to systemic therapy, lung reexpansion after the drainage of pleural fluid, and estimated survival. The objective in palliative treatment is the permanent elimination of pleural fluid. The cases that have limited effusion recurrence or in which full remission is not observed among patients with pressure symptoms because of pleural effusion fluid are defined as a partial success. It should be noted that the treatment of malignant pleural effusion is the local control of the disease, and it has no effect on the underlying systemic disease (5).

\section{Therapeutic Thoracentesis}

Although therapeutic thoracentesis is an effective way in the elimination of symptoms, most malignant pleural effusions are repeated within a month. If the patient's Karnofsky Performance Scale score is good (>30), thoracentesis should not be the only preferred treatment method. Furthermore, repeated thoracentesis carries the risk of pneumothorax and empyema (6). 

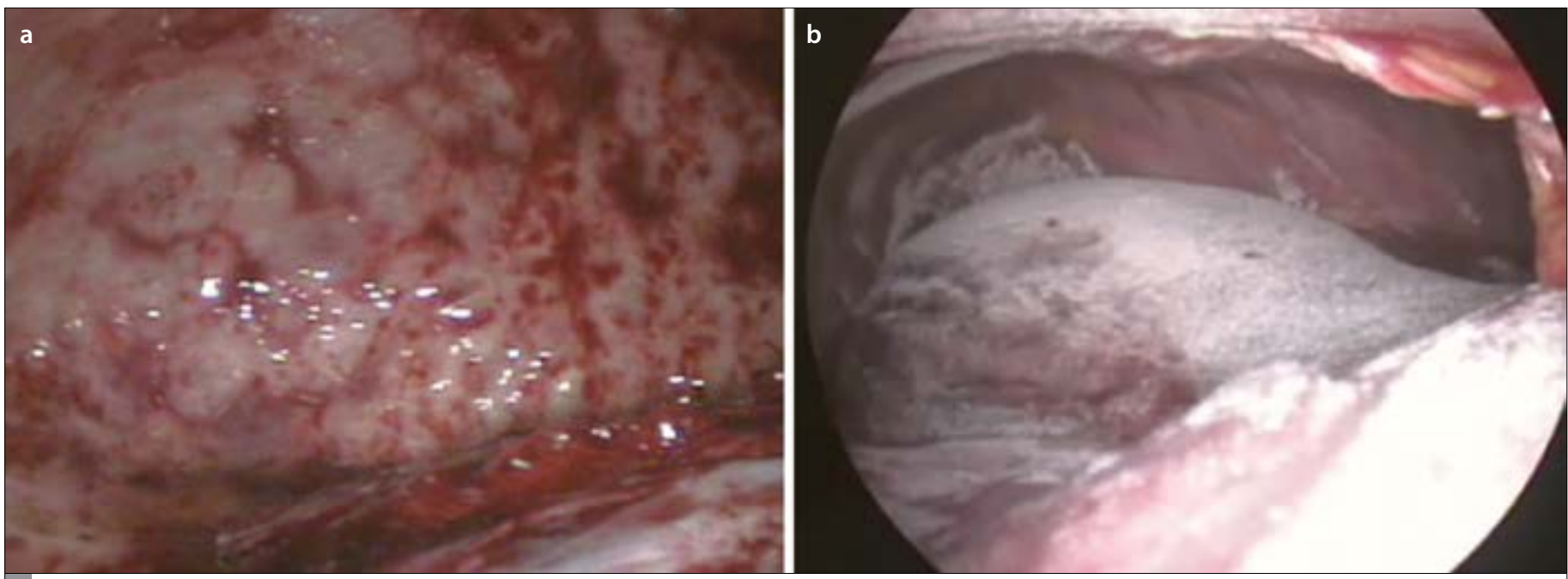

Figure 1. a, b. Parietal pleural involvement of lung cancer (a); appearance after talc poudrage during videothoracoscopy (b)

\section{Pleurodesis}

Malignant pleural effusion can be effectively treated with the complete drainage of fluid and administration of intrapleural sclerosing agent. For a successful pleurodesis, the lung should be reexpanded, and it should be in contact with the parietal pleura. A pleurodesis sclerosing agent is administered into the pleural space with an intercostal catheter/tube or by the thoracoscopic talc poudrage method (7-9). Commonly used sclerosing agents are talc, tetracyclines, and bleomycin $(1,3,9)$. The success rate is $81-100 \%$ for talc, $65-76 \%$ for tetracycline, and $61 \%$ for bleomycin $(1,3,9,10)$. Side effects such as fever and pleuritic chest pain are more commonly observed with talc application. Additionally, when talc particle size smaller than $15 \mu \mathrm{m}$ is applied, talc application-linked acute respiratory distress syndrome (ARDS) cases have been reported in the United Kingdom and United States $(11,12)$. Maskell et al. (13) showed that in patients where talc particle size smaller than $15 \mu \mathrm{m}$ is used, in the $48^{\text {th }}$ hour, the alveolar-arterial oxygen gradient is higher than that in patients administered talc particle size greater than $15 \mu \mathrm{m}$. In another multicenter study in which 508 patients were evaluated, when talc particle size greater than $15 \mu \mathrm{m}$ is used, death, ARDS or pneumonia is not observed in any patient (14).

According to the 36 randomized controlled studies in the Cochrane database, the results in 1499 patients who underwent pleurodesis support the use of an intrapleural sclerosing agent to prevent recurrence if the patients' performance status is good, the use of a talc agent, and the use of thoracoscopic talc poudrage application technique (2). In a systematic compilation, thoracoscopic talc poudrage and tube thoracostomy talc application were compared, and recurrence after the thoracoscopic method was shown to be lower (15).

Stefani et al. (16), who randomized 109 patients with thoracoscopic pleurodesis and tube thoracostomy application as pleurodesis groups, showed that the thoracoscopic approach has a better early $(87.5 \%$ vs. $73 \%)$ and lifetime ( $81 \%$ vs. $55 \%)$ success. In another study, it is stated that especially in effusions with $\mathrm{pH}<7.3$, the thoracoscopic method is superior to tube thoracostomy and that the reason for this superiority is the opening of intrapleural adhesions during thoracoscopy caused by low $\mathrm{pH}$ and the provision of complete drainage (17).
A survey in which 859 physicians participated revealed that the majority of the participants prefer talc as the sclerosing agent and thoracoscopic pleurodesis as the method (18). Longer survival is found in patients with a successful pleurodesis (19). In in vitro studies, this longer survival is explained with the ability of talc to cause apoptosis of lung cancer and mesothelioma cells and with endostatin induction pleural spaces, which is an angiogenic and biologically active environment, conversion to an angiostatic medium (20-22). In the most comprehensive randomized controlled study conducted by Dresler et al. (23), 482 patients were administered 4-5 g of talc with tube thoracostomy or thoracoscopic insufflation in order to investigate whether thoracoscopic pleurodesis is superior to pleurodesis with tube thoracostomy. In this study, after the 30-day follow-up, in patients with lung or breast cancer who underwent thoracoscopy, less recurrence was observed compared with those who underwent tube thoracostomy (18\%-33\%). In a retrospective study conducted in Süreyyapaşa Chest Diseases and Thoracic Surgery Hospital between January 2008 and January 2011, a total of 100 patients who underwent video thoracoscopy $(n=61)$ and tube thoracostomy $(n=39)$ with talc were compared, and despite the lack of a significant difference, it was observed that the recurrence is lower in video thoracoscopy (23.9\%, 10.2\%). In this study, the overall survival was calculated as 2.7 months in both groups (24).

In video thoracoscopy, it is preferred to use a double lumen endotracheal tube under general anesthesia in order to ensure one-lung ventilation $(5,25)$. However, in some patients with a high risk for general anesthesia, surgery may be performed using systemic analgesic, sedative drugs and a combination of local anesthetic agents (5). For video thoracoscopy, the patient is placed in the lateral decubitus position. After proper cleaning and preparation, a $2 \mathrm{~cm}$ thoracoscopy incision is made in the sixth or seventh intercostal space usually in the mid-axillary line level. Apart from this port, one or two more port incisions may be made in the appropriate intercostal spaces. After the drainage of pleural fluid, a thoracoscope is placed, and after the pleural cavity is examined, a pleural biopsy is taken. During the procedure, adhesions are opened with the help of thoracoscopic instruments. In case of trapped lung detection, lung reexpansion should be provided through limited decortication. When it is seen that the 


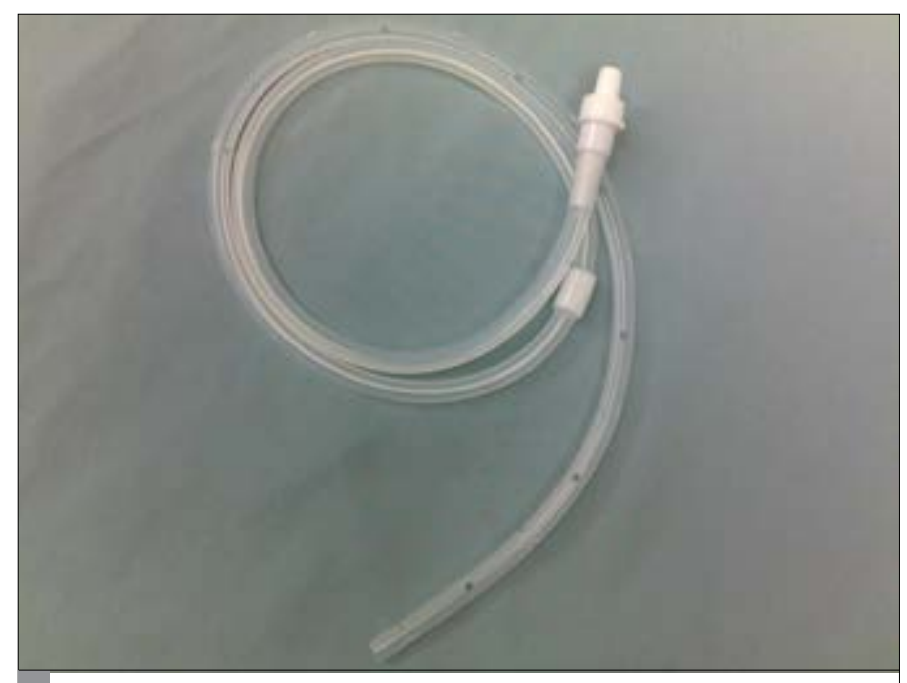

Figure 2. PleurX catheter

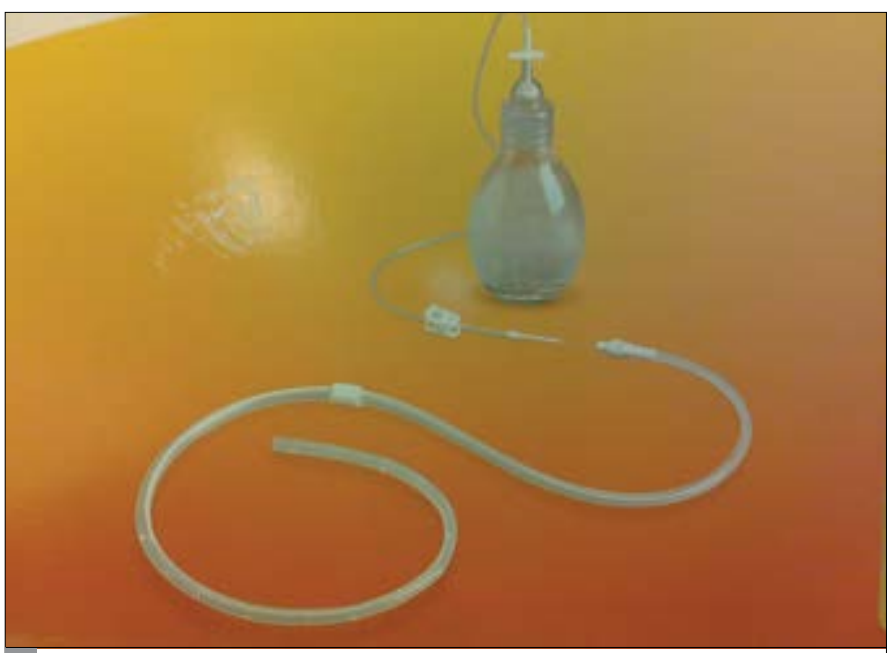

Figure 3. PleurX catheter and vacuumed bottle

lung fills the rib cage, with the help of an atomizer, 4-5 g of talc was applied into the rib cage via insufflation by covering all the visceral pleura (Figure 1a, b). After talc application, one chest tube is placed, and the operation is concluded.

When thoracoscopic pleurodesis and pleurodesis via tube thoracotomy are compared, it is observed that respiratory complications occur more frequently with thoracoscopic pleurodesis (14\% vs. $6 \%$ ). Other common complications of thoracoscopy are dyspnea and pain. Other rare complications are post-operative fever, continuous air leak, hemorrhage, subcutaneous emphysema, reexpansion pulmonary edema, deep vein thrombosis, and port site metastasis $(2,3,5)$.

\section{Fluid Drainage with Indwelling Pleural Catheter}

Pleural fluid drainage with indwelling pleural catheter is an alternative method to thoracoscopic pleurodesis. For patients whose lung is not expanded despite effusion drainage, for advanced cancer patients with short life expectancy, for unsuccessful pleurodesis in symptomatic loculated effusions, or depending on the patient's preference, the decision to use an indwelling catheter may be made
$(10,26)$. An indwelling catheter placed via tunnel technique in symptomatic patients provides symptomatic relief by allowing the drainage of pleural fluid. An advantage of the process is the patient being discharged home with the indwelling catheter. The maintenance and drainage of pleural fluid catheter with 2-3 day intervals can be conducted by visiting nurses or by the patient/patient relatives after proper training. In a series of 250 patients in a single center, within 2-6 weeks after an indwelling catheter placement, $40 \%$ of cases reported that catheter had been removed because of spontaneous pleurodesis development (26). The complications related to the placement of an indwelling catheter are catheter malfunction (9.1\%), pneumothorax requiring chest tube drainage (5\%), pain and catheter occlusion (3.7\%), empyema (2.8\%), cellulitis (3.4\%), and tumor metastasis along the catheter track (1\%) (27). In a study where cost comparison between the tube thoracostomy pleurodesis and indwelling catheter technique was made, in cases where the patient's survival is longer than 6 weeks, the cost of tube thoracostomy method is shown to be lower (28). As with the use of targeted chemotherapy agents in the treatment of advanced cancer, because a longer survival duration is aimed, cost will become an important issue in these patients (29).

The indwelling pleural catheter used in the United States is PleurX (Denver Biomedical, Golden, $\mathrm{CO}$ ) catheter. This catheter is $66 \mathrm{~cm}$ long and is a 15.5-F flexible silicone catheter (Figure 2). At the distal end of the catheter, multiple fenestrations are available. At the proximal end of the catheter, there is a one-way valve that prevents the involuntary drainage of the fluid. The polyester cuff $14 \mathrm{~cm}$ from the proximal end provides the adhesion of catheter under the skin. The catheter should be placed under sedation in sterile conditions. The catheter is placed with the Seldinger method after locating the pleural fluid with the help of needles. First, a guide wire is passed through the needle and is advanced into the rib cage, and an approximately 1 $\mathrm{cm}$ skin incision is made in this region. This subcutaneous tunnel is made by making a second incision approximately $5 \mathrm{~cm}$ from the first incision in the costal arch's medial. The catheter is passed through this tunnel, and the cuff is placed under the skin. A sheath dilator is passed over the wire guide, and the dilator and guidewire are withdrawn. The catheter is inserted into the thorax through the sheath, and the sheath is removed by tearing. The catheter is fixed to the skin. Skin incisions are closed. After placement, all effusions can be discharged. After the patient is discharged, the patient or the person who is responsible for catheter care periodically drains the pleural fluid by connecting the catheter to a disposable vacuum chamber (Figure 3).

\section{Pleuroperitoneal Shunt}

If lung expansion is inadequate after the drainage of the effusion and if the lung does not completely fill the rib cage, a pleuroperitoneal shunt may be placed. This process is performed under local or general anesthesia. After a 3-cm transverse incision is made into the rectus sheath, the peritoneal cavity is examined. The pump chamber of the catheter is placed in a subcutaneous pocket on the costal arch. A subcutaneous tunnel is made toward the thorax and abdomen. The pleural and abdominal ends are respectively placed in the rib cage and abdomen, and the process is concluded. The patient or nurse sends the intrathoracic fluid into the abdomen by pressing the subcutaneous pump at regular intervals throughout the day. Shunt complications are shunt occlusion and infection. Approximately $10 \%$ 
of patients experience shunt occlusions, and the shunts of these patients should be replaced. Planting peritoneal tumor with a pleuroperitoneal shunt is a potential risk $(5,30)$.

\section{Advanced Surgical Procedures-Cytoreductive Surgery}

In the presence of malignant pleural effusion, surgery should be a part of multimodality treatment if it is to be applied as a "curative purpose." Such surgical applications are defined as cytoreductive surgery. This is because even in a major aggressive surgery such as extrapleural pneumonectomy, to achieve "real" negative margins through resection of the pleura is virtually impossible. Even though no macroscopic tumors remain with these surgeries, there certainly will be tumors at the microscopic level. Without complementary modalities after the curative resection of malignant pleural effusion, a high rate of local recurrence is observed. The complementary modalities of surgery are radiotherapy, hyperthermic intraoperative chemotherapy, and photodynamic therapy. Because mortality and morbidity are very high in multimodal treatments, patient selection is very important $(31,32)$.

For cytoreductive surgical procedures (pleurectomy, decortication, and extrapleural pneumonectomy), after standard double lumen endotracheal intubation, the patient is placed in the lateral decubitus position. With a standard posterolateral thoracotomy incision, the skin, subcutaneous, latissimus dorsi muscles are incised. To provide an adequate point of view, serratus muscle may be performed with sparing thoracotomy. In some cases, in order to reach the costophrenic recess and to evaluate the diaphragm in a better way, resection of the sixth or seventh costas can be performed.

\section{CONCLUSION}

New developments are still needed in the treatment of malignant pleural effusion. Pleurodesis is effective in symptom control but is not the ideal technique. Pleurodesis application methods should be specifically selected for a patient. Although indwelling catheters are a good alternative to pleurodesis, patient care requirements and complication risks are the limiting factors. Cytoreductive surgery procedures such as pleurectomy do not prevent the development of recurrence alone.

Peer-review: Externally peer-reviewed.

Author contributions: Concept - T.Ç., S.T.; Design - T.Ç., S.T.; Supervision - T.Ç., S.T.; Resource - T.Ç., S.T.; Materials - T.Ç., S.T.; Data Collection and/or Processing - T.Ç., S.T.; Analysis and/or Interpretation - T.Ç., S.T.; Literature Search - T.Ç., S.T.; Writing - T.Ç., S.T.; Critical Reviews - T.Ç., S.T.; Other - T.Ç., S.T.

Conflict of Interest: No conflict of interest was declared by the authors.

Financial Disclosure: The authors declared that this study has received no financial support.

\section{REFERENCES}

1. American Thoracic Society. Management of malignant plural effusions. Am J Respir Care Med 2000; 162: 1987-2001. [CrossRef]

2. Shaw P, Agarwal R. Pleurodesis for malignant pleural effusions. Cochrane Database Syst Rev 2004; 1: CD002916. [CrossRef]

3. Roberts ME, Neville E, Berrisford RG, Antunes G, Ali NJ; BTS Pleural Disease Guideline Group. Management of a malignant pleural effusion: British Thoracic Society Pleural Disease Guideline 2010. Thorax 2010; 65: ii32-40. [CrossRef]
4. Anderson $\mathrm{CB}$, Philpott GW, Ferguson TB. The treatment of malignant pleural effusions. Cancer 1974; 33: 916-22. [CrossRef]

5. Cetinkanat CG, Willimas M, Pass HI. Thoracoscopy with interpleural sclerosis for malignant pleural effusion. In Sugarbaker DJ, Bueno R, Krasna MJ, Mentzer SJ, Zellos L, eds. Adult Chest Surgery. McGraw-Hill; 2009: 855-9.

6. Burrows $\mathrm{CM}$, Mathews WC, Colt HG. Predicting survival in patients with recurrent symptomatic malignant pleural effusions: an assessment of the prognostic values of physiologic, morphologic and quality of life measures of extent of disease. Chest 2000; 117: 73-8. [CrossRef]

7. Kennedy L, Rusch VW, Strange C, Ginsberg RJ, Sahn SA. Pleurodesis using talc slurry. Chest 194; 106: 342-6. [CrossRef]

8. Steger V, Mika U, Toomes H, Walker T, Engel C, Kyriss T, et al. Who gians most? A 10-year experience with 611 thoracoscopic talc pleurodesis. Ann Thorac Surg 2007; 83: 1940-5. [CrossRef]

9. Walker-Renard PB, Vaughan LM, Sahn SA. Chemical pleurodesis for malignant pleural effusions. Ann Intern Med 1994; 120: 56-64. [CrossRef]

10. Heffner JE. Diagnosis and management of malignant pleural effusions. Respiralogy 2008; 13: 5-20.

11. Kennedy L, Sahn SA. Talc pleurodesis fort he treatment of pneumothorax nd pleural effusion. Chest 1994; 106: 1215-22. [CrossRef]

12. Campos JR, Werebe EC, Vargas FS, Jatene FB, Light RW. Respiratory failure due to insufflated talc. Lancet 1997; 349: 251-2. [CrossRef]

13. Maskell NA, Lee YC, Gleeson FV, Hedley EL, Pengelly G, Davies RJ. Randomized trials describing lung inflammation after pleurodesis with talc of varying particle size. Am J Respir Critcare Med 2004; 170: 377-82. [CrossRef]

14. Janssen JP, Collier G, Astoul P, Tassi GF, Noppen M, Rodriguez-Panadero F et al. Safety of pleurodesis with talc poudrage in malignant pleural effusion: a prospective cohort study. Lancet 2007; 369: 1535-9. [CrossRef]

15. Tan C, Sedrakyan A, Browne J, Swift S, Trasure T. The evidence on the effectivenessof management of malignant pleural effusion: a systemic review. Eur J Cardiothorac Surg 2006; 29: 829-38. [CrossRef]

16. Stefani A, Natali P, Casali C, Morandi U. Talc poudrage versus talc slurry in the treatment of malignant pleural effusion. A prospective comprative study. Eur J Cardiothorac Surg 2006; 30: 827-32. [CrossRef]

17. Crnjac A, Sok M, Kamenik M. Impact of pleural effusion $\mathrm{pH}$ on the efficacy of thoracoscopic mechanical pleurodesis in patients with breast carcinoma. Eur J Cardiothorac Surg 2004; 26: 432-6. [CrossRef]

18. Lee YC, Baumann MH, Maskell NA, Waterer GW, Eaton TE, Davies RJ, et al. Pleurodesis practice for malignant pleural effusions in five English-speaking countries: survey of pulmonologists. Chest 2003; 124: 2229-38. [CrossRef]

19. Aelony Y, Yao JF. Prolonged survival after talc poudrage for malignant pleural mesothelioma: case series. Respirology 2005; 10: 649-55. [CrossRef]

20. Nasreen N, Mohammed KA, Dowling PA, Ward MJ, Galffy G, Antony VB. Talc induces apoptosis in human malignant mesothelioma cells in vitro. Am J Respir Crit Care Med 2000; 161: 595-600. [CrossRef]

21. Lee $P$, Sun L, Lim CK, Aw SE, Colt HG. Selective apoptosis of lung cancer cells with talc. Eur Respir J 2010; 35: 450-2. [CrossRef]

22. Nasreen N, Mohammed KA, Brown S, Su Y, Sriram PS, Moudgil B, et al. Talc mediates angiostasis in malignant pleural effusions via endostatin induction. Eur Respir J 2007; 29: 761-9. [CrossRef]

23. Dresler CM, Olak J, Herndon JE 2nd, Richards WG, Scalzetti E, Fleishman SB, et al. Cooperative Groups Cancer and Leukemia Group B; Eastern Cooperative Oncology Group; North Central Cooperative Oncology Group; Radiation therapy Oncology Group. Phase III intergroup study of talc poudrage vs talc slurry sclerosis for malignant pleural effusion. Chest 2005; 127: 909-15. [CrossRef]

24. Alpay L, Laçin T, Kıral H, Mısırlıoğlu A, Demir M, Ocakcıoğlu I, ve ark. Semptomatik malign plevral efüzyonlu hastaların tedavisinde video-yardımlı torakoskopik talk pudraj ile tüp torakostomiden talk uygulamasının karşılaştırılması. 6. Ulusal Göğüs Cerrahisi Kongresi; 28 Nisan - 1 Mayıs 2011, Antalya. 
25. Brega-Massone PP, Conti B, Magnani B, Ferro F, Leguaglie C. Minimally invasive thoracic surgery for diagnostic assessment and palliative treatment in recurrent neoplastic pleural effusion. Thorac Cardiovasc Surg 2004; 52: 191-5. [CrossRef]

26. Tremblay A, Michaud G. Single-center experience with 250 tunnelled pleural catheter insertions for malignant pleural effusion. Chest 2006; 129: 362-8. [CrossRef]

27. Van Meter ME, McKee KY, Kohlwes RJ. Efficacy and safety of tunneled pleural catheters in adults with malignant pleural effusions: a systematic review. J Gen Intern Med 2011; 26: 70-6. [CrossRef]

28. Olden AM, Holloway R. Treatment of malignant pleural effusion: PleurX catheter or talc pleurodesis? A cost-effectiveness analysis. J Palliat Med 2010; 13: 59-65. [CrossRef]
29. Langer CJ, Besse B, Gualberto A, Brambilla E, Soria JC. The evolving role of histology in the management of advanced non-small-cell lung cancer J Clin Oncol 2010; 28: 5311-20. [CrossRef]

30. Al-Katten KM, Kaplan DK, Goldstraw P. The nonfunctioning pleuroperitoneal shunt: revise or replace? Thorac Cardiovasc Surg 1994; 42: 310-2.

31. Fry WA, Khandekar JD. Parietal pleurectomy for malignant pleural effusion. Ann Surg Oncol 1993; 2: 160-4. [CrossRef]

32. Friedberg JS. Photodynamic therapy in the management of malignant pleural effusions. In: In Sugarbaker DJ, Bueno R, Krasna MJ, Mentzer SJ, Zellos L, eds. Adult Chest Surgery. McGraw-Hill; 2009: 891-9. 